Supporting information to accompany

\title{
Releasable Luciferin-Transporter Conjugates: Tools for the Real Time Analysis of Cellular Uptake and Release
}

Lisa R. Jones, Elena A. Goun, Rajesh Shinde, Jonathan B. Rothbard, Christopher H. Contag, and Paul A. Wender*

Departments of Chemistry, Molecular Pharmacology, and Pediatrics, Stanford University, Stanford, California 94305-5080

\section{Contents}

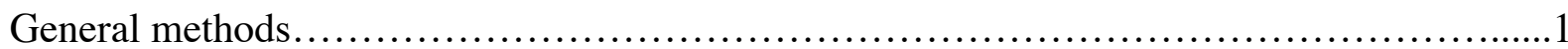

Synthesis and characterization of luciferin octa L-arginine conjugates $2-5 \ldots \ldots \ldots \ldots \ldots \ldots \ldots . . .2$

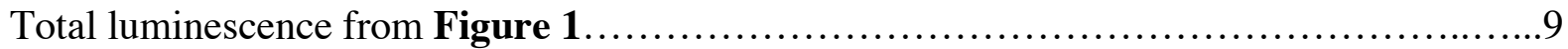

Cell free assay for the release of luciferin from conjugates $\mathbf{5 b}$ and $\mathbf{5} \mathbf{c} \ldots \ldots \ldots \ldots \ldots \ldots \ldots$

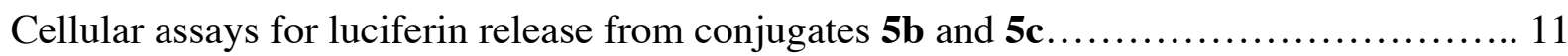

Assays measuring the release of luciferin from and decomposition of conjugates 5 a-c......11

\section{General methods}

Unless otherwise stated, all reagents and solvents were obtained from commercial sources and used without purification. Analytical TLC was performed with $0.25 \mathrm{~mm}$ silica gel $60 \mathrm{~F}$ plates with fluorescent indicator $(254 \mathrm{~nm})$. Plates were visualized by ultraviolet light and treatment with either ammonium molybdate stain (prepared by combining $90 \mathrm{~g}$ of ammonium molybdate, $6 \mathrm{~g}$ of cerium sulfate, and $1800 \mathrm{~mL}$ of $10 \% \mathrm{H}_{2} \mathrm{SO}_{4}$ ) or potassium permanganate stain (prepared by combining $8 \mathrm{~g}$ of $\mathrm{KMnO}_{4}, 60$ $\mathrm{g}$ of $\mathrm{K}_{2} \mathrm{CO}_{3}, 16 \mathrm{~mL}$ of $5 \% \mathrm{NaOH}$, and $900 \mathrm{~mL} \mathrm{H}_{2} \mathrm{O}$ ). Reverse-phase high performance liquid chromatography (RP-HPLC) was performed with a Varian ProStar 210/215 HPLC using a preparative column (Alltec Alltima C18, 250 x $22 \mathrm{~mm}$ ) or on an Agilent 1100 analytical HPLC with an analytical column (Vydak C18, $150 \times 4.6 \mathrm{~mm}$ ). The products were eluted utilizing a solvent gradient (solvent $\mathrm{A}=$ $0.1 \% \mathrm{TFA} / \mathrm{H}_{2} \mathrm{O}$; solvent $\mathrm{B}=0.1 \% \mathrm{TFA} / \mathrm{CH}_{3} \mathrm{CN}$ ). NMR spectra were measured on a Varian INOVA 500 $\left({ }^{1} \mathrm{H} \mathrm{NMR}\right.$ at $500 \mathrm{MHz} ;{ }^{13} \mathrm{C} \mathrm{NMR}$ at $\left.125 \mathrm{MHz}\right)$ or a Varian INOVA $400\left({ }^{1} \mathrm{H} \mathrm{NMR}\right.$ at $400 \mathrm{MHz} ;{ }^{13} \mathrm{C} \mathrm{NMR}$ at $100 \mathrm{MHz}$ ) magnetic resonance spectrometer. Data for ${ }^{1} \mathrm{H}$ NMR spectra are reported as follows: chemical shift, multiplicity $(\mathrm{s}=$ singlet, $\mathrm{d}=$ doublet, $\mathrm{dd}=$ doublet of doublet, $\mathrm{t}=$ triplet, $\mathrm{q}=$ quartet, and $\mathrm{m}=$ multiplet), integration, and coupling constant $(\mathrm{Hz})$. Data for ${ }^{1} \mathrm{H}$ NMR and ${ }^{13} \mathrm{C}$ NMR spectra are 
reported in terms of chemical shift relative to residual solvent peak $\left(\mathrm{CDCl}_{3}: 7.26\right.$ and $77.3 \mathrm{ppm}$ and $\mathrm{CD}_{3} \mathrm{OD}: 4.97$ and $49.1 \mathrm{ppm}$ (for ${ }^{1} \mathrm{H}$ NMR and ${ }^{13} \mathrm{C}$ NMR spectra respectively). Infrared spectra were recorded on a Perkin-Elmer 1600 Series FTIR. High resolution mass spectra (HRMS) were recorded at the NIH regional mass spectrometry facility at the University of California, San Francisco. Electrospray ionization mass spectra (ES-MS) were recorded at the mass spectrometry lab at Stanford University on a Finnigan LCQ quadrupole ion trap mass spectrometer. Matrix Assisted Laser Desorption mass spectra (MALDI) were recorded on an Applied Biosystems Voyager DE mass spectrometer.

\section{Synthesis and characterization of luciferin octa L-arginine conjugates 2-5}

\section{Compound 2a}<smiles>OCCSSc1ccccn1</smiles>

To an oven dried three-necked flask under nitrogen at room temperature equipped with a stir bar was added 2'-aldrithiol (4.71 g, $21.4 \mathrm{mmol})$ in $20 \mathrm{~mL}$ methanol purged with nitrogen. To this mixture was added 2-mercaptoethanol dropwise $(500 \mu \mathrm{L}, 7.10 \mathrm{mmol})$. The solution turned yellow and was allowed to stir for two hours. The solvent was then removed in vacuo and flash chromatography was performed using $20 \%$ ethyl acetate and methylene chloride. The product was a yellow oil (1.320 g, $7.06 \mathrm{mmol}, 97 \%$ yield) and homogeneous (one spot) by TLC $\mathrm{R}_{\mathrm{f}}=0.47$ (5\% EtOAc, DCM).

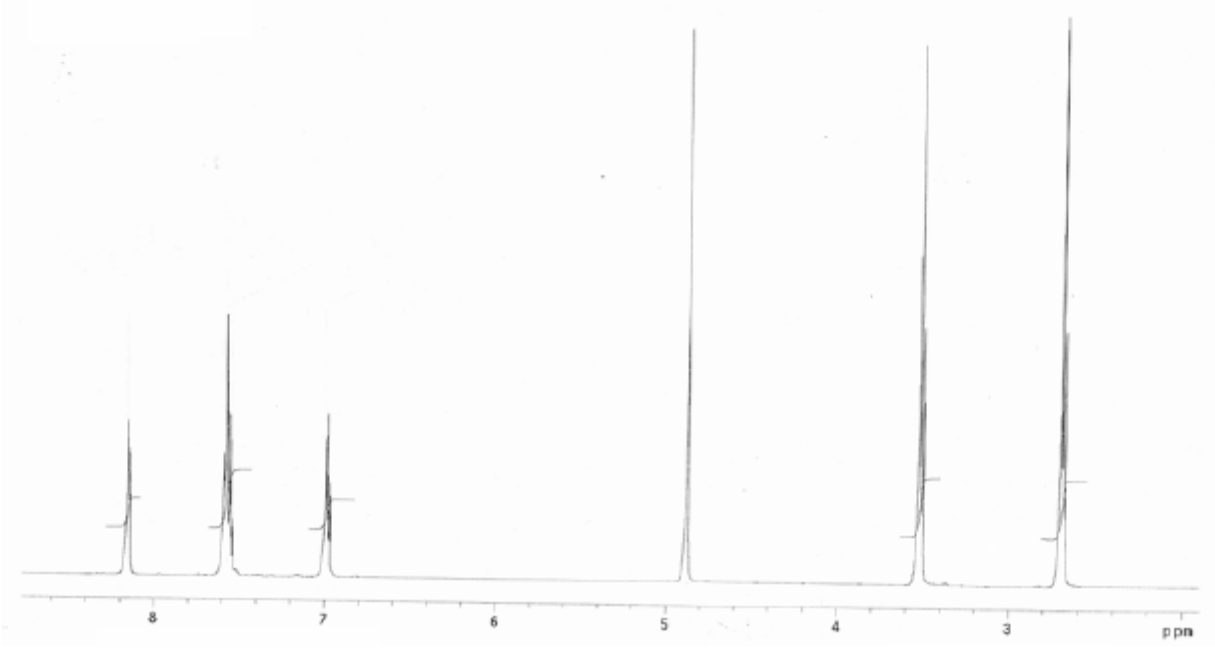

${ }^{1} \mathrm{H}$ NMR (500 MHz, $\left.\mathrm{CD}_{3} \mathrm{OD}\right): \delta 8.15-8.14(\mathrm{~m}, 1 \mathrm{H}), 7.59-7.53(\mathrm{~m}, 2 \mathrm{H}), 7.00-6.97(\mathrm{~m}, 1 \mathrm{H}), 3.51(\mathrm{t}, 2 \mathrm{H}, J$ $=6.5 \mathrm{~Hz}), 2.68(\mathrm{t}, 2 \mathrm{H}, J=6.5 \mathrm{~Hz}) \mathrm{ppm} .{ }^{13} \mathrm{C} \mathrm{NMR}\left(100 \mathrm{MHz}, \mathrm{CDCl}_{3}\right): \delta \quad 159.3,150.0,137.1,122.0$, 121.7, 58.5, 42.8 ppm. IR (thin film): 3349, 2920, 2865, 1574, 1559, 1446, 1285, 1116, $1063 \mathrm{~cm}^{-1}$. HRMS (m/z): $[\mathrm{M}+]$ calculated for $\mathrm{C}_{7} \mathrm{H}_{9} \mathrm{NOS}_{2}$ : 187.0126; found: 187.0123 . 


\section{Compound 2b}

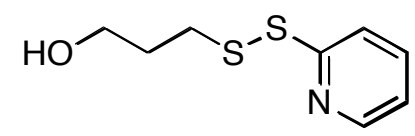

Compound $\mathbf{2 b}$ was synthesized as described above for 2a beginning with the 3-mercapto-1propanol in $91 \%$ yield.

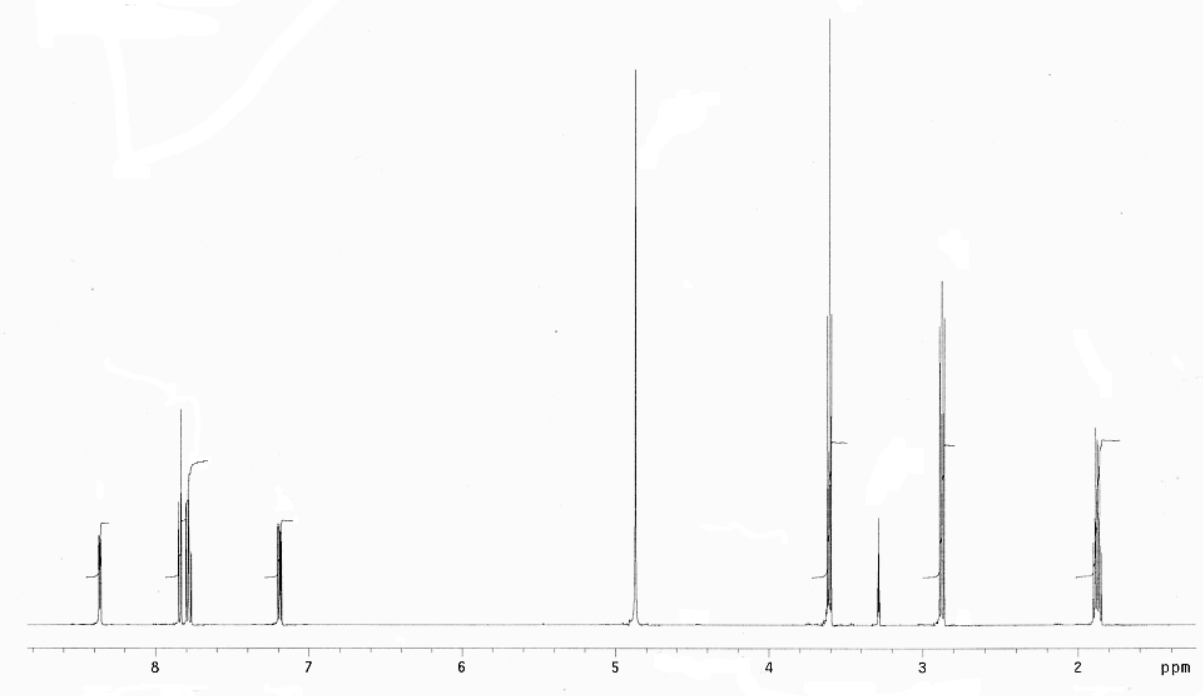

${ }^{1} \mathrm{H}$ NMR (500 MHz, $\left.\mathrm{CD}_{3} \mathrm{OD}\right): \delta 8.37-8.35(\mathrm{~m}, 1 \mathrm{H}), 7.85-7.83(\mathrm{~m}, 1 \mathrm{H})$, 7.79-7.77 (m, 1H), 7.20-7.18 (m, $1 \mathrm{H}), 3.60(\mathrm{t}, 2 \mathrm{H}, J=6.5 \mathrm{~Hz}), 2.87(\mathrm{t}, 2 \mathrm{H}, J=6.5 \mathrm{~Hz}), 1.87(\mathrm{~m}, 2 \mathrm{H}) \mathrm{ppm} .{ }^{13} \mathrm{C} \mathrm{NMR}\left(125 \mathrm{MHz}, \mathrm{CD}_{3} \mathrm{OD}\right)$ : $\delta 161.0,149.5,139.5,122.2,121.2,60.7,36.1,32.5$ ppm. IR (thin film) $3359,2934,1784,1688,1574$, $1446 \mathrm{~cm}^{-1}$. EI-MS (m/z): [M+] calculated for $\mathrm{C}_{8} \mathrm{H}_{11} \mathrm{NOS}_{2}$ 201.0282; found 201.0275.

\section{Compound 2c}

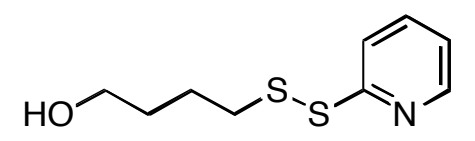

Compound $\mathbf{2 c}$ was synthesized as described above for $\mathbf{2 a}$ beginning with the 4-mercapto-1butanol in $82 \%$ yield. 


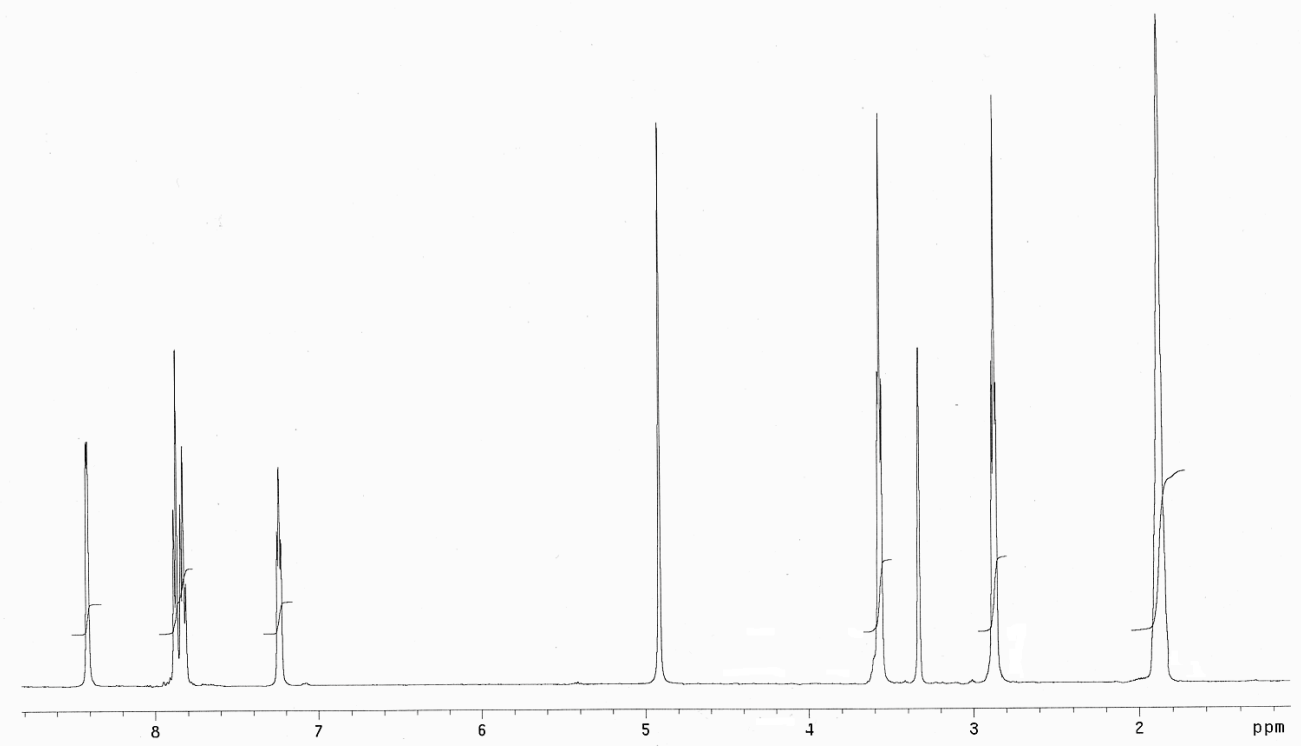

${ }^{1} \mathrm{H}$ NMR (500 MHz, $\left.\mathrm{CD}_{3} \mathrm{OD}\right): \delta$ 8.45-8.43 (m, 1H), 7.91-7.86 (m, 2H), 7.25-7.18 (m, 1H), $3.59(\mathrm{t}, 2 \mathrm{H}, J$ $=6.5 \mathrm{~Hz}), 2.87(\mathrm{t}, 2 \mathrm{H}, J=6.5 \mathrm{~Hz}), 1.92-1.85(\mathrm{~m}, 4 \mathrm{H}) \mathrm{ppm} .{ }^{13} \mathrm{C} \mathrm{NMR}\left(100 \mathrm{MHz}, \mathrm{CDCl}_{3}\right): \delta 160.6$, 149.7, 137.3, 120.9, 112.9, 62.3, 38.9. 31.6. 25.5 ppm. IR (thin film): 3365, 2933, 2863, 1575, 1560, 1446, 1440, 1118, 1062, $1044 \mathrm{~cm}^{-1}$. HRMS (m/z): [M+] calculated for $\mathrm{C}_{9} \mathrm{H}_{13} \mathrm{NOS}_{2}$ 215.0439; found 215.0433.

\section{Compound $4 \mathbf{a}$}<smiles>O=C(OCCSSc1ccccn1)Oc1ccc2nc(C3=N[C@H](C(=O)O)CS3)sc2c1</smiles>

To an oven dried flask equipped with a stir bar and a Teflon cap under argon was added 2a (44.0 $\mathrm{mg}, 0.235 \mathrm{mmol})$, triphosgene $(25.0 \mathrm{mg}, 0.0842 \mathrm{mmol})$, and pyridine $(18.0 \mu \mathrm{L}, 0.222 \mathrm{mmol})$ in methylene chloride $(3 \mathrm{~mL})$ at room temperature. The solution remained clear. This was allowed to stir for 30 minutes then the solvent was evaporated in vacuo to afford a white foam. To this was added luciferin potassium salt $(30.0 \mathrm{mg}, 94.3 \mu \mathrm{mol})$ and $\mathrm{NaOH}(547 \mu \mathrm{L}$ of $0.5 \mathrm{M}, 0.273 \mathrm{mmol})$ in water $(3 \mathrm{~mL})$ that had been chilled in brine and ice. The solution turned cloudy white, purple then cloudy yellow. The reaction was stirred for 4 hours at $4{ }^{\circ} \mathrm{C}$, quenched with $1 \%$ TFA and water $(15 \mathrm{~mL})$ and extracted three times with methylene chloride. The solvent was evaporated in vacuo the compound was purified using flash chromatography with $20 \%$ ethyl acetate, $1 \%$ acetic acid, and methylene chloride. The appropriate fractions were isolated then further purified by RP-HPLC. Appropriate fractions were lyophilized to afford a yellow solid ( $27 \mathrm{mg}, 54.5 \mu \mathrm{mol}, 58 \%$ ), which was homogeneous (one spot) by TLC $\mathrm{R}_{\mathrm{f}}=0.40$ (20\% EtOAc, $1 \%$ acetic acid, DCM). 


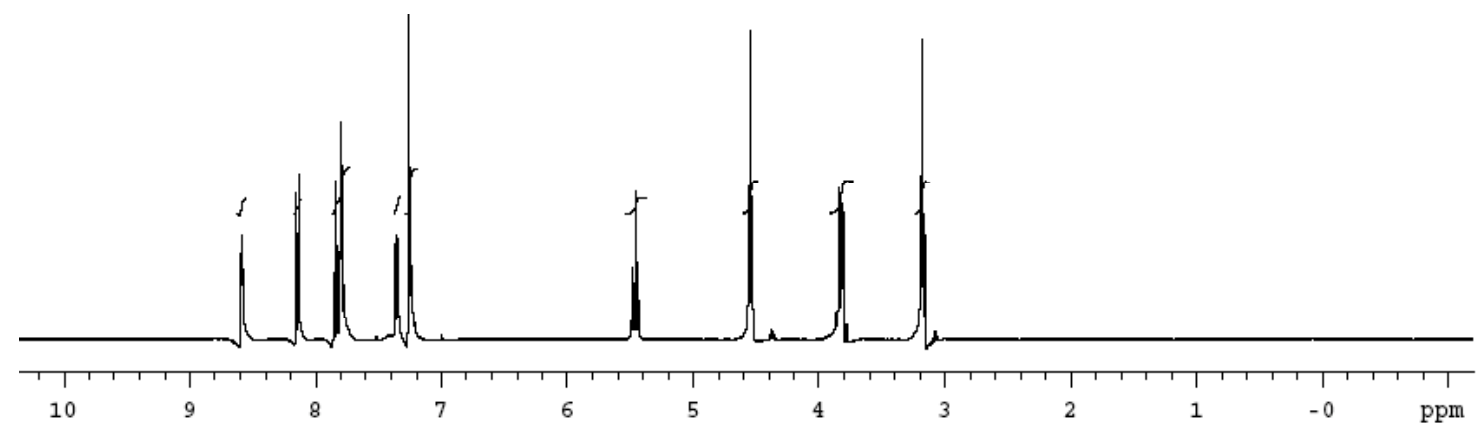

${ }^{1} \mathrm{H}$ NMR $\left(400 \mathrm{MHz}, \mathrm{CDCl}_{3}\right): \delta 8.59-8.58(\mathrm{~m}, 1 \mathrm{H}), 8.15(\mathrm{~d}, 1 \mathrm{H}, J=9.0 \mathrm{~Hz}), 7.85-7.77(\mathrm{~m}, 3 \mathrm{H}), 7.36(\mathrm{dd}$, $1 \mathrm{H}, J=9.0 \mathrm{~Hz}), 7.23-7.23(\mathrm{~m}, 1 \mathrm{H}), 5.46$ (t, 1H, $J=8.4 \mathrm{~Hz}), 4.55(\mathrm{t}, 2 \mathrm{H}, J=8.4 \mathrm{~Hz}), 3.84-3.81(\mathrm{~m}, 2 \mathrm{H})$, $3.18(\mathrm{t}, 2 \mathrm{H}, J=8.4 \mathrm{~Hz}) \mathrm{ppm} .{ }^{13} \mathrm{C} \mathrm{NMR}\left(125 \mathrm{MHz}, \mathrm{CDCl}_{3}\right): \delta 172.9,167.5,161.0,159.2,153.3,151.3$, 150.0, 148.8, 139.0, 137.9, 130.6, 125.6, 122.0, 121.2, 114.5, 78.2, 66.5, 37.3, 35.4 ppm. IR (thin film): 3350, 2952, 2360, 1761, 1587, 1448, 1418, 1201, 1196, $1043 \mathrm{~cm}^{-1}$. EI-MS (m/z): [M+1] calculated for $\mathrm{C}_{19} \mathrm{H}_{16} \mathrm{~N}_{3} \mathrm{O}_{5} \mathrm{~S}_{4} 493.9$; found 493.9 .

\section{Compound $4 \mathrm{~b}$}

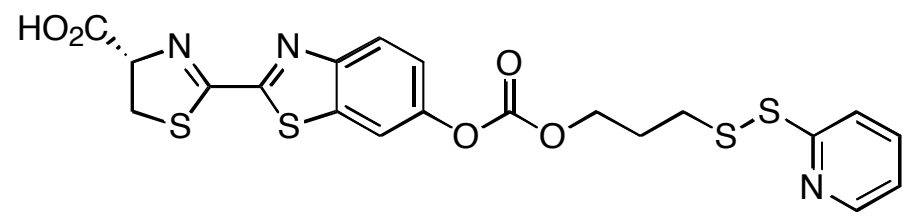

Compound $\mathbf{4 b}$ was synthesized as described above for $\mathbf{4 a}$ beginning with $\mathbf{2 b}$ in $47 \%$ yield and $>99 \%$ purity by analytical HPLC.

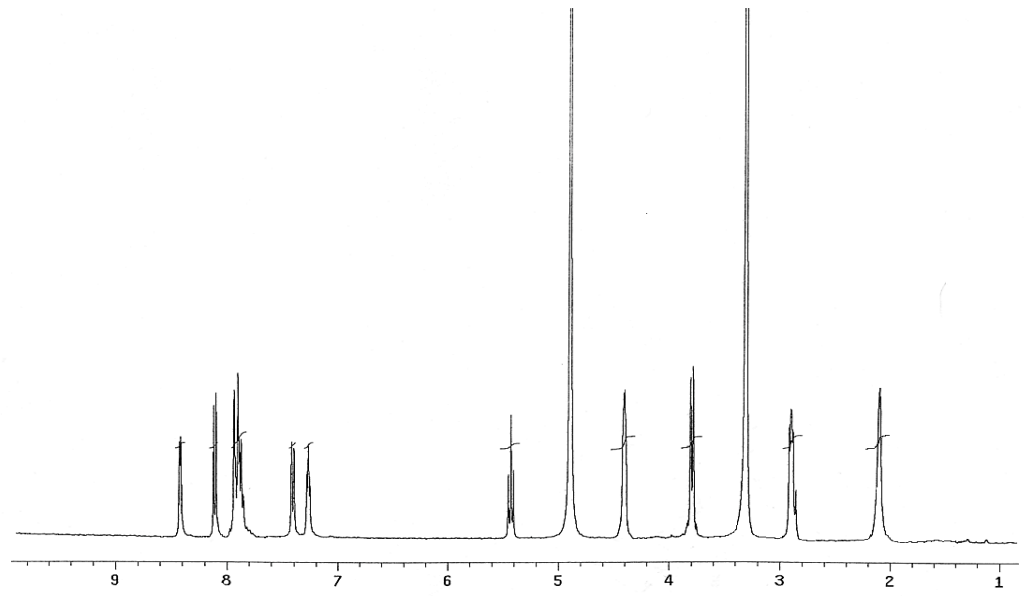

${ }^{1} \mathrm{H}$ NMR (500 MHz, CD $\left.{ }_{3} \mathrm{OD}\right): \delta 8.43(\mathrm{~m}, 1 \mathrm{H}), 8.11(\mathrm{~d}, 1 \mathrm{H}, J=9.0 \mathrm{~Hz}), 7.97(\mathrm{~d}, 1 \mathrm{H}, J=2.0 \mathrm{~Hz}), 7.86$ $(\mathrm{m}, 1 \mathrm{H}), 7.81(\mathrm{~m}, 1 \mathrm{H}), 7.44(\mathrm{dd}, 1 \mathrm{H}, J=9.0 \mathrm{~Hz}), 7.27(\mathrm{~m}, 1 \mathrm{H}), 5.46(\mathrm{t}, 1 \mathrm{H}, J=9.0 \mathrm{~Hz}), 4.41(\mathrm{t}, 2 \mathrm{H}, J=$ $6.5 \mathrm{~Hz}), 3.81(\mathrm{dd}, 2 \mathrm{H}, J=9.0 \mathrm{~Hz}), 2.95(\mathrm{t}, 2 \mathrm{H}, J=6.5 \mathrm{~Hz}), 2.16(\mathrm{~m}, 2 \mathrm{H}) \mathrm{ppm} .{ }^{13} \mathrm{C}$ NMR $(125 \mathrm{MHz}$, $\left.\mathrm{CD}_{3} \mathrm{OD}\right): \delta 168.1,162.9,161.2,154.7,152.2,151.5,150.4,139.1,137.9,130.4,125.8,122.4,121.3$, 
121.2, 115.8, 79.7, 68.3, 43.8, 35.9, $29.1 \mathrm{ppm}$. IR (thin film) 3045, 2958, 1761, 1574, 1417, $1236 \mathrm{~cm}^{-1}$. EI-MS (m/z): [M+1] calculated for $\mathrm{C}_{20} \mathrm{H}_{18} \mathrm{~N}_{3} \mathrm{O}_{5} \mathrm{~S}_{4}$ 508.00; found 508.06.

\section{Compound 4c}

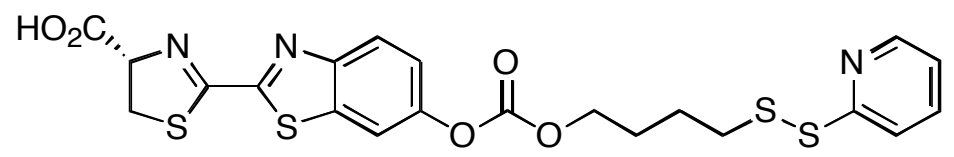

Compound $\mathbf{4 c}$ was synthesized as described above for $\mathbf{4 a}$ beginning with $\mathbf{2 c}$ in $67 \%$ yield. The product was homogeneous (one spot) by TLC $\mathrm{R}_{\mathrm{f}}=0.56$ (20\% EtOAc, $1 \%$ acetic acid, DCM).

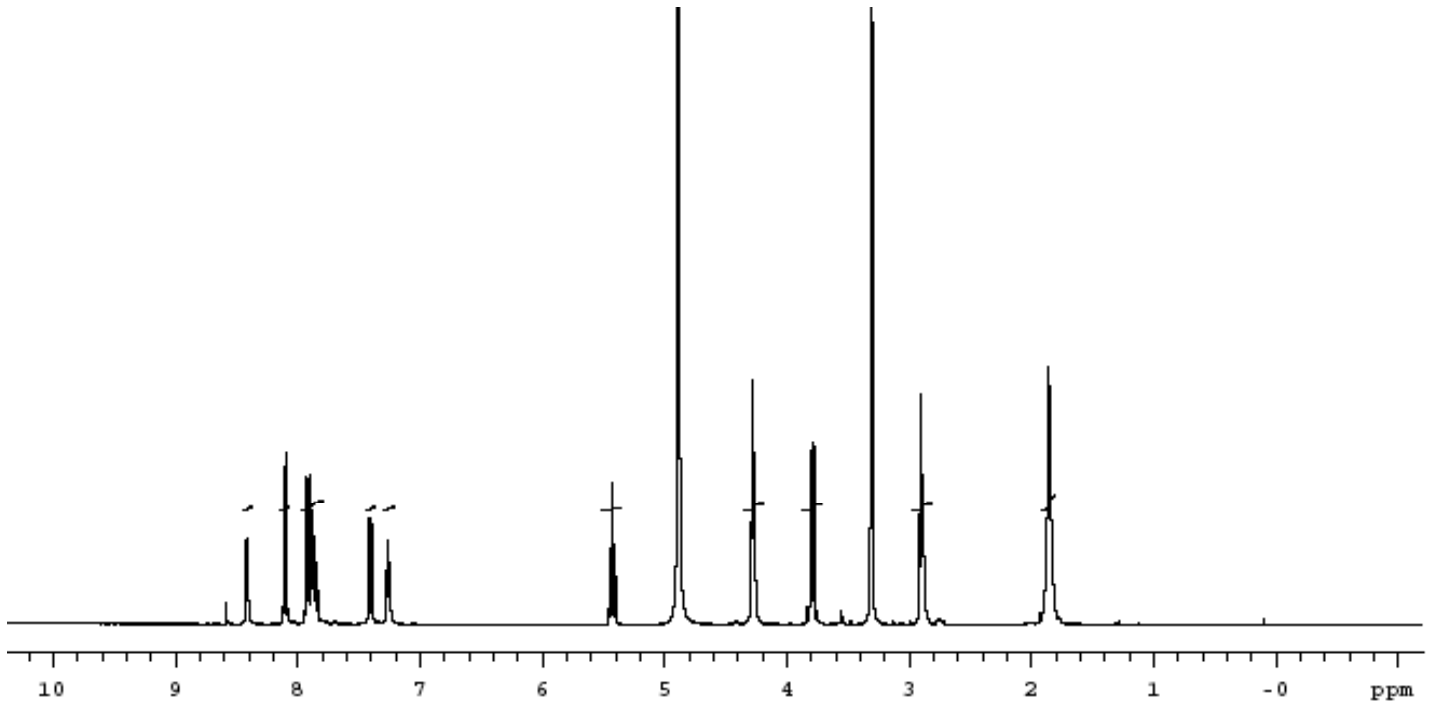

${ }^{1} \mathrm{H}$ NMR $\left(400 \mathrm{MHz}, \mathrm{CD}_{3} \mathrm{OD}\right): \delta$ 8.42-8.41 (m, $\left.1 \mathrm{H}\right), 8.10(\mathrm{~d}, 1 \mathrm{H}, J=8.8), 7.93-7.83(\mathrm{~m}, 3 \mathrm{H}), 7.41(\mathrm{dd}$, $1 \mathrm{H}, J=8.8 \mathrm{~Hz}), 7.27-7.24(\mathrm{~m}, 1 \mathrm{H}), 5.42(\mathrm{t}, 1 \mathrm{H}, J=8.8 \mathrm{~Hz}), 4.27$ (t, $2 \mathrm{H}, J=6.0 \mathrm{~Hz}), 3.79(\mathrm{dd}, 2 \mathrm{H}, J=$ 8.8), $2.89(\mathrm{t}, 2 \mathrm{H}, J=6.8), 1.86-1.83(\mathrm{~m}, 4 \mathrm{H}) \mathrm{ppm} .{ }^{13} \mathrm{C} \mathrm{NMR}\left(125 \mathrm{MHz}, \mathrm{CDCl}_{3}\right): \quad \delta 171.9,167.45,160.7$, 159.2, 153.3, 151.2, 149.9, 148.5, 138.8, 136.7, 130.5, 125.3, 121.6, 121.1, 114.3, 75.5, 66.4 38.9, 37.1, 35.3, 30.3 ppm. IR (thin film): 2937, 1760, 1586, 1496, 1447, 1417, 1231, 1197, 1043, $874 \mathrm{~cm}^{-1}$. EI-MS $(\mathrm{m} / \mathrm{z}):[\mathrm{M}+1]$ calculated for $\mathrm{C}_{21} \mathrm{H}_{20} \mathrm{~N}_{3} \mathrm{O}_{5} \mathrm{~S}_{4} 522.02$; found 522.0 .

\section{Compound 5a}

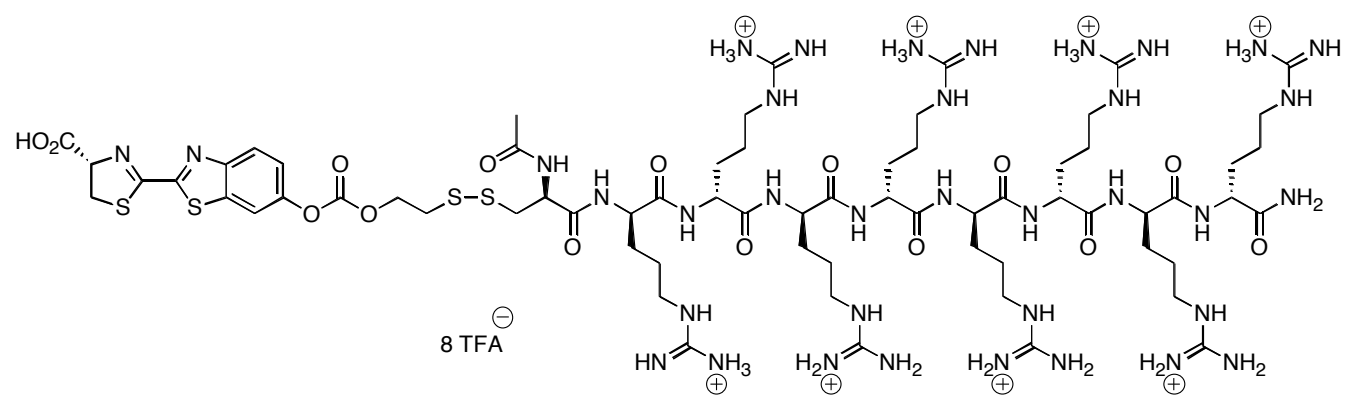


To an oven dried test tube under nitrogen equipped with a stir bar was added Ac-D-Cys-(D-Arg $)_{8}$ $\mathrm{CONH}_{2} \bullet$ 8 TFA $(20 \mathrm{mg}, 8.61 \mu \mathrm{mol})$ in dimethylforamide $(2 \mathrm{ml})$. To this was added $\mathbf{4 a}(7.10 \mathrm{mg} 14.4$ $\mu \mathrm{mol}$ ) in $0.5 \mathrm{ml}$ dimethylforamide. The reaction was allowed to stir for 16 hours then purified by RPHPLC. Appropriate fractions were lyophilized to afford a white solid (15 mg, $5.54 \mu \mathrm{mol}, 64 \%$ yield) which was $>99 \%$ pure by analytical HPLC.

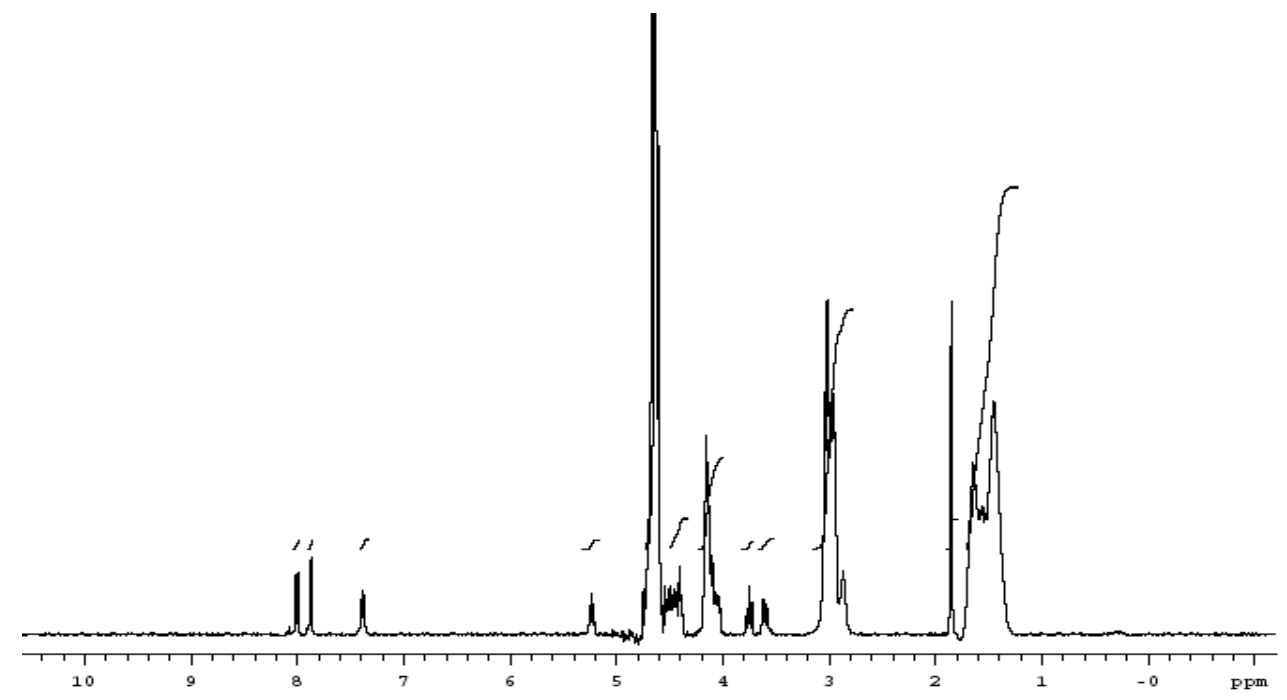

${ }^{1} \mathrm{H}$ NMR $\left(400 \mathrm{MHz}, \mathrm{D}_{2} \mathrm{O}\right): \delta 8.00(\mathrm{~d}, 1 \mathrm{H}, J=8.8 \mathrm{~Hz}), 7.87(\mathrm{~d}, J=2.0,1 \mathrm{H}), 7.38(\mathrm{dd}, 1 \mathrm{H}, J=9.0 \mathrm{~Hz})$, $5.23(\mathrm{t}, 1 \mathrm{H}, J=8.8 \mathrm{~Hz}), 4.41-4.38(\mathrm{~m}, 2 \mathrm{H}), 4.15-4.02(\mathrm{~m}, 9 \mathrm{H}), 3.78-3.58(\mathrm{~m}, 2 \mathrm{H}), 3.05-2.87(\mathrm{~m}, 20 \mathrm{H})$, $1.88(\mathrm{~s}, 3 \mathrm{H}), 1.66-1.45(\mathrm{~m}, 32 \mathrm{H}) \mathrm{ppm}$. MS (m/z): [M+3] calculated for $\mathrm{C}_{67} \mathrm{H}_{119} \mathrm{~N}_{36} \mathrm{O}_{15} \mathrm{~S}_{4}$ 1795.8; found (MALDI) 1795.8.

\section{Compound 5b}

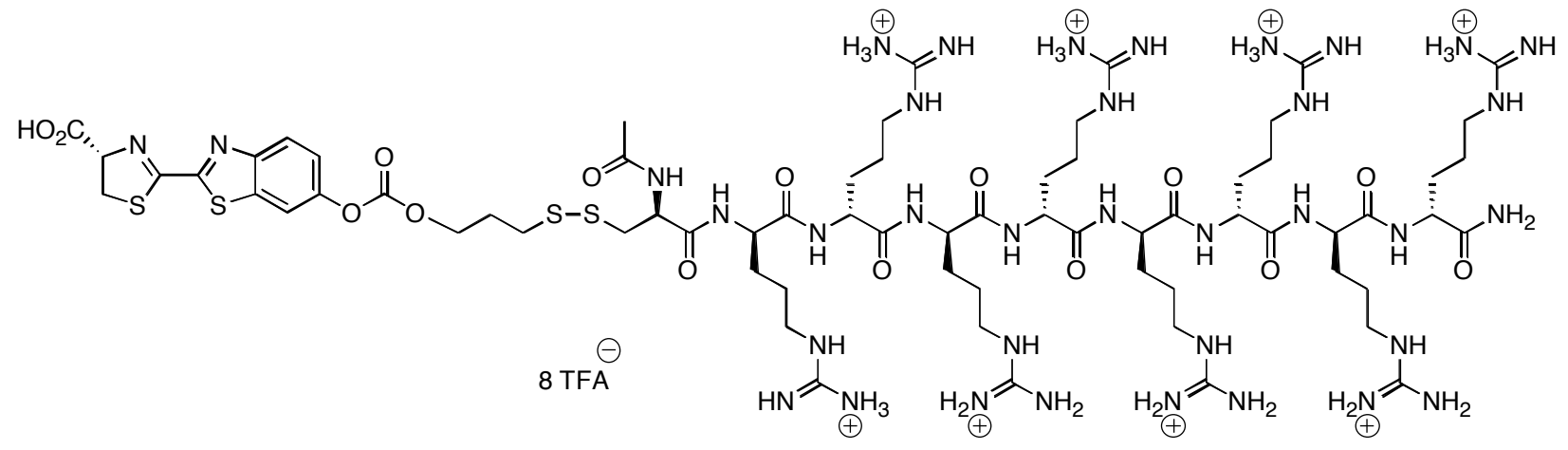

Conjugate $\mathbf{5 b}$ was synthesized, as described above for $\mathbf{5 a}$ beginning with compound $\mathbf{4 b}$ and AcD-Cys-(D-Arg) $)_{8}-\mathrm{CONH}_{2} \bullet 8 \mathrm{TFA}$, in $66 \%$ yield and $>99 \%$ pure by analytical HPLC. 


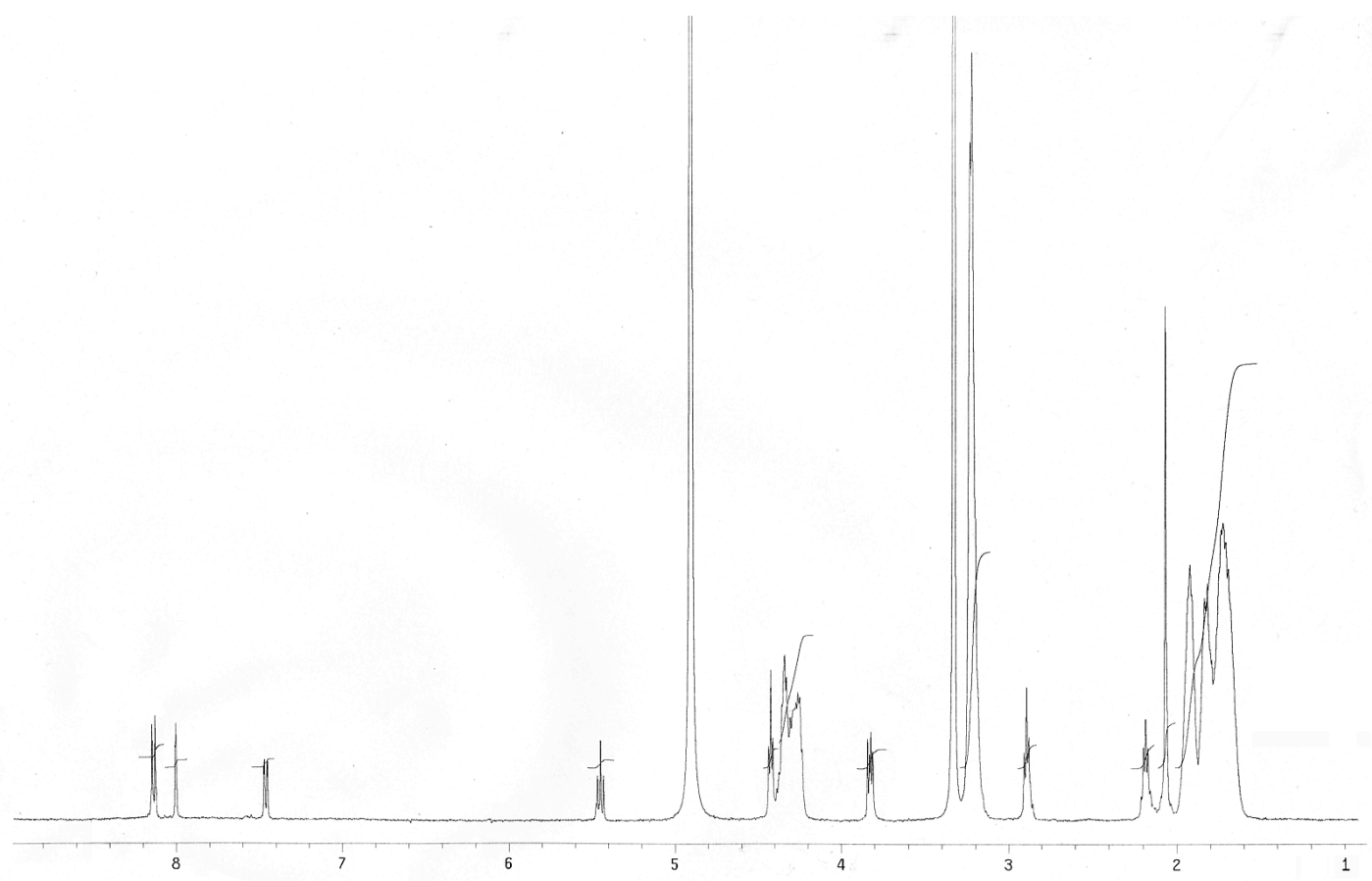

${ }^{1} \mathrm{H}$ NMR (500 MHz, CD 3 OD): $\delta 8.16$ (d, 1H, $J=9.0 \mathrm{~Hz}$ ), 7.99 (d, 1H, $J=2.0 \mathrm{~Hz}$ ), 7.46 (dd, 1H, $J=9.0$ $\mathrm{Hz}), 5.46(\mathrm{t}, 1 \mathrm{H}, J=9.0 \mathrm{~Hz}), 4.42(\mathrm{t}, 2 \mathrm{H}, J=6.5 \mathrm{~Hz}), 4.27-4.35(\mathrm{~m}, 9.0 \mathrm{H}), 3.81(\mathrm{dd}, 2 \mathrm{H}, J=9.0 \mathrm{~Hz})$, 3.15-3.23 (m, 18H), $2.91(\mathrm{t}, 2 \mathrm{H}, J=6.5 \mathrm{~Hz}), 2.17(\mathrm{~m}, 2 \mathrm{H}), 2.05(\mathrm{~s}, 3 \mathrm{H}), 1.60-1.95(\mathrm{~m}, 32 \mathrm{H}) \mathrm{ppm} . \mathrm{MS}$ (m/z): [M+1] calculated for $\mathrm{C}_{68} \mathrm{H}_{119} \mathrm{~N}_{36} \mathrm{O}_{15} \mathrm{~S}_{4}$ 1807.85; found (MALDI) 1807.84.

\section{Compound 5c}

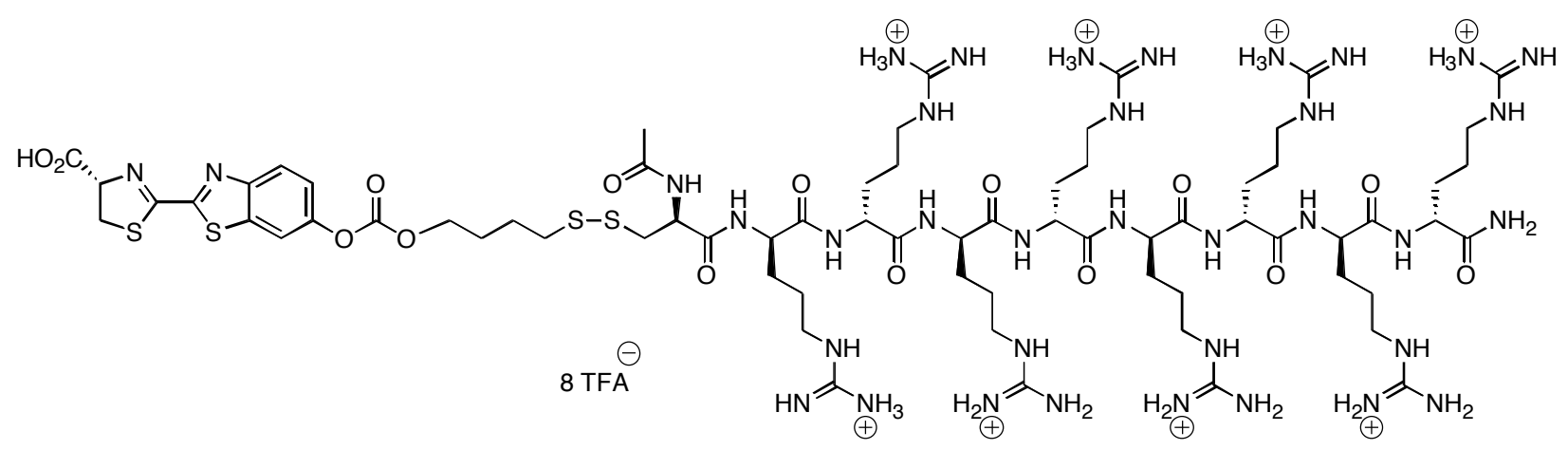

Conjugate $\mathbf{5 c}$ was synthesized as described above for $\mathbf{5 a}$ beginning with compound $\mathbf{4 c}$ and Ac-DCys-(D-Arg) $)_{8}-\mathrm{CONH}_{2} \bullet 8 \mathrm{TFA}$ in $24 \%$ yield and $>99 \%$ pure by analytical HPLC. 


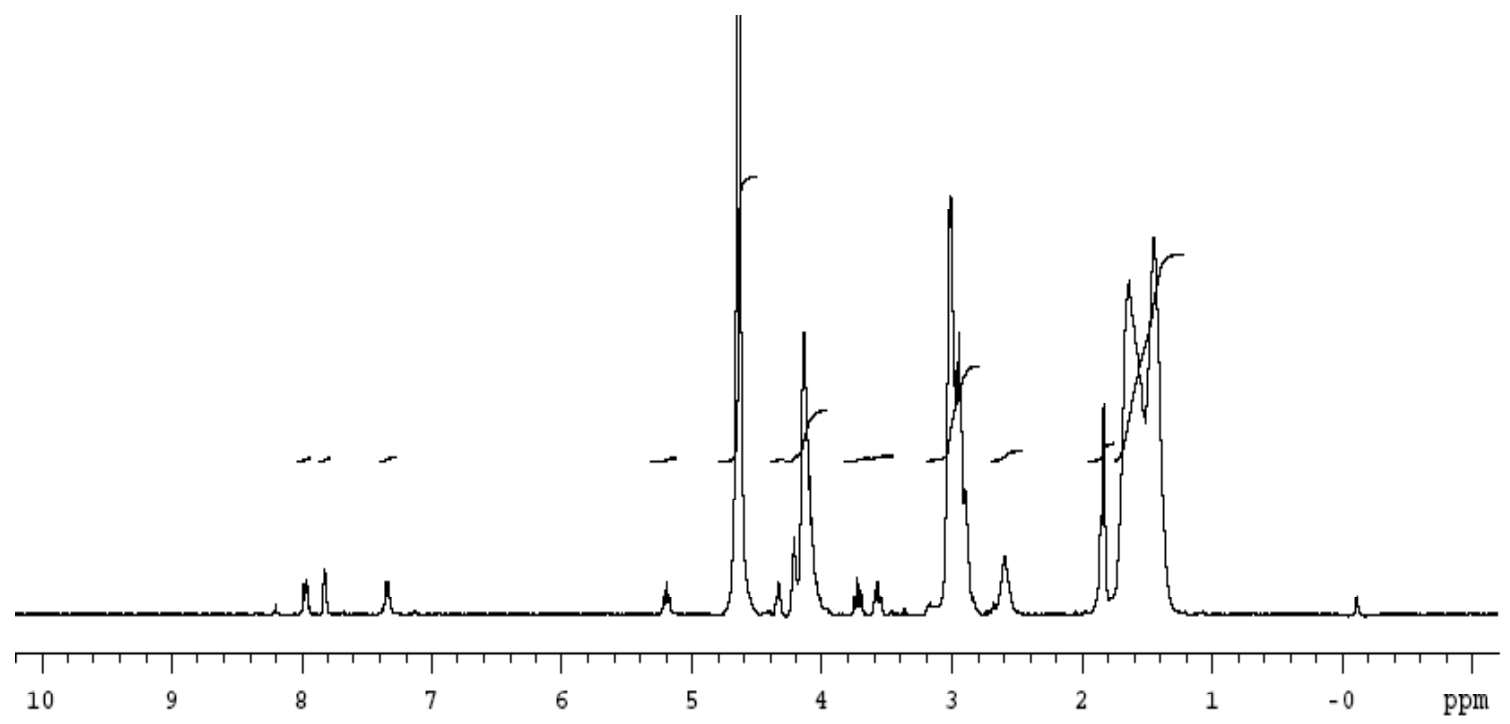

${ }^{1} \mathrm{H}$ NMR $\left(400 \mathrm{MHz}, \mathrm{D}_{2} \mathrm{O}\right): \delta 7.97(\mathrm{~d}, 1 \mathrm{H}, J=8.8 \mathrm{~Hz}) 7.82(\mathrm{~d}, 1 \mathrm{H}, J=2.0), 7.34(\mathrm{dd}, 1 \mathrm{H}, J=8.8$ $\mathrm{Hz}), 5.17$ (t, 1H, J = 8.8 Hz), 4.22-4.04 (m, 11H), 3.75-3.55 (m, 2H), 3.02-2.83 (m, 18H), 2.68$2.59(\mathrm{~m}, 2 \mathrm{H}), 1.83(\mathrm{~s}, 3 \mathrm{H}), 1.64-1.45(\mathrm{~m}, 36 \mathrm{H}) \mathrm{ppm}$. MS (m/z): [M+2] calculated for $\mathrm{C}_{69} \mathrm{H}_{122} \mathrm{~N}_{36} \mathrm{O}_{15} \mathrm{~S}_{4}$ 1822.86; found (MALDI) 1822.05 (M+1).

\section{Total luminescence from Figure 1}

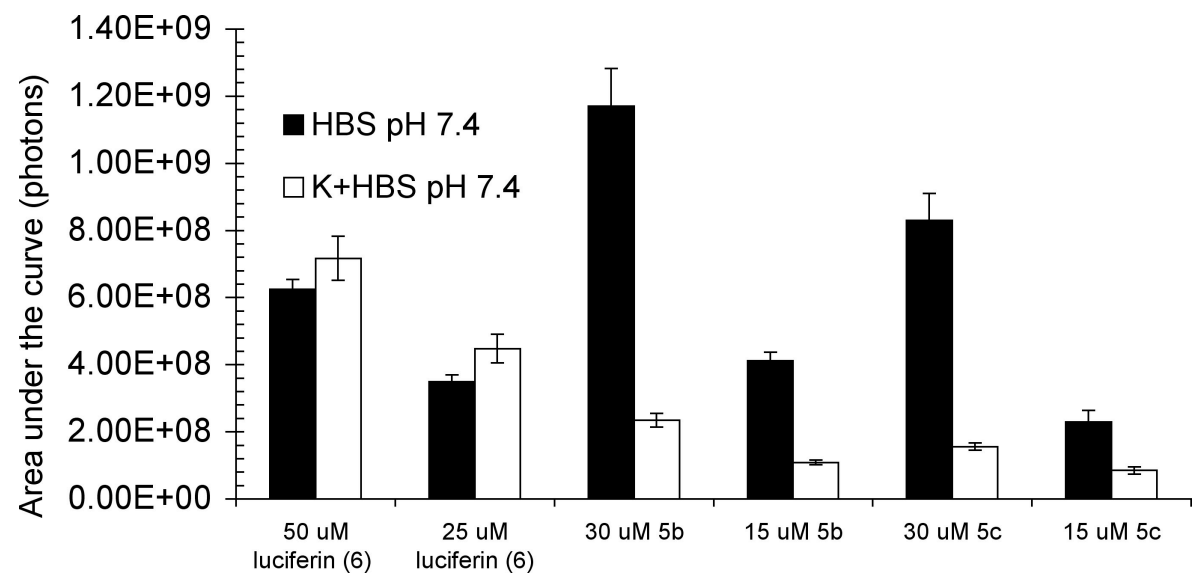

Figure 1. Total bioluminescence from a prostate cancer cell line stably transfected with luciferase (PC3M-luc) treated with $25 \mathrm{mM}$ luciferin $(\mathbf{6})$ or $15 \mathrm{mM}$ releasable luciferin conjugates, $\mathbf{5 b}$ or $\mathbf{5 c}$, in either HBS or $\mathrm{K}+\mathrm{HBS}$.

\section{Cell free assay for the release of luciferin from conjugates $5 \mathrm{~b}$ and $5 \mathrm{c}$}

The relative rates of release of luciferin from conjugates $\mathbf{5 b}$ or $\mathbf{5 c}$ in a reducing environment were measured by incubating varying concentrations of the conjugates with firefly luciferase (Promega, Madison,WI) and measuring the resultant luminescence as a function of time using a luminometer 
(Berthold Detection Systems, model: Sirius). Standard curves measuring the amount of light generated by luciferin were produced by adding varying concentrations (from 20-2000 $\mathrm{nM}$ ) of the potassium salt of luciferin (Xenogen Corp., Alameda, CA) in $50 \mu \mathrm{L}$ of $5 \mathrm{mM} \mathrm{MgSO}_{4}, 200 \mathrm{mM} \mathrm{NaCl}, 20 \mathrm{mM}$ HEPES, 1 mM EDTA pH 7.4 to $100 \mathrm{ng}$ of firefly luciferase in $50 \mu \mathrm{L}$ of the same buffer containing $1 \mathrm{mM}$ DTT, 2 mM ATP. The light produced was found to be linear in the concentration range used in this study (Figure 2).
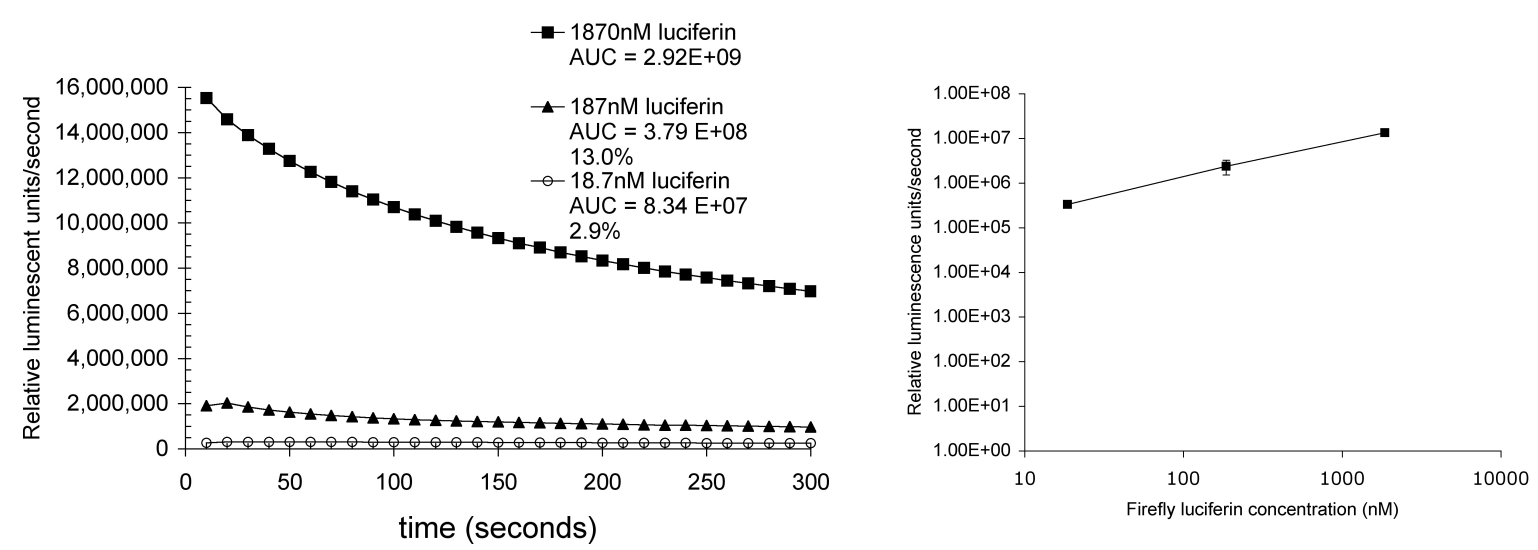

Figure 2. Standard curves of luminescence resulting from the addition of known amount of luciferin to 100 ng of firefly luciferase in $5 \mathrm{mM} \mathrm{MgSO}_{4}, 200 \mathrm{mM} \mathrm{NaCl}, 20 \mathrm{mM}$ HEPES, 1 mM EDTA, 1 mM DTT, 2 mM ATP pH 7.4 (Left panel); Units for the integrated area under the curves (AUC) are photons. The percentiles represent normalized amounts of light to the highest dose of luciferin. (Right panel); A linear relationship was observed when the log of the concentration was plotted as a function of the log of the concentration of luciferin.

To determine the relative rates of release of luciferin from the conjugates in a reducing environment, $50 \mu \mathrm{L}$ of a $50 \mu \mathrm{M}$ solution of carbonate $\mathbf{5 b}$ and $\mathbf{5 c}$ in $5 \mathrm{mM} \mathrm{MgSO}_{4}, 200 \mathrm{mM} \mathrm{NaCl}, 20 \mathrm{mM}$ HEPES, 1 mM EDTA pH 7.4 were added to $100 \mathrm{ng}$ of firefly luciferase in $50 \mu \mathrm{L}$ of the same buffer containing $1 \mathrm{mM}$ DTT, $2 \mathrm{mM}$ ATP and the resultant light measured. There was a significant difference in light produced, with carbonate $\mathbf{5 c}$ generating only approximately $12 \%$ of the light generated by carbonate 5b (Figure 3A). Equivalent molar amounts of luciferin were released from each conjugate as established by preincubation with $1 \mathrm{mM}$ DTT for 20 minutes prior to the addition of the enzyme. Under these conditions, the profile of luminescence was similar to that seen with purified luciferin (Figure 2) and equivalent amounts of light was observed for both conjugates. (Figure 3B).

One possible explanation for the differences is the life-time of the intermediate of $\mathbf{5 c}$ is much greater than that for $\mathbf{5 b}$, allowing it to compete with released luciferin for the binding site of luciferase. 
This hypothesis is supported by the fact that the 6-O methyl ether of luciferin, similarly alkylated at the phenol, is a known inhibitor of luciferase. ${ }^{5}$
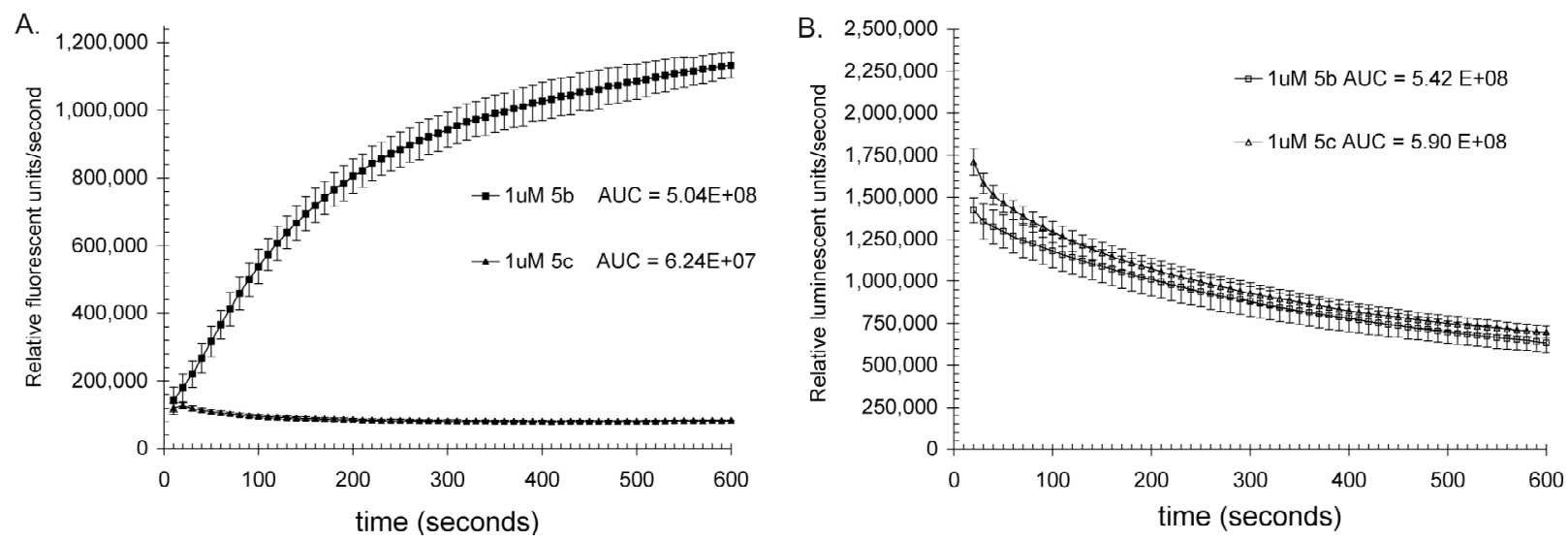

Figure 3. Differential luminescence produced when carbonate $\mathbf{5 b}$ and $\mathbf{5 c}$ were mixed with luciferase. Resultant luminescence when $1 \mu \mathrm{M}$ solutions of carbonate $\mathbf{5 b}$ and $\mathbf{5 c}$ were mixed with $100 \mathrm{ng}$ of firefly luciferase in $5 \mathrm{mM}$ $\mathrm{MgSO}_{4}, 200 \mathrm{mM} \mathrm{NaCl}, 20 \mathrm{mM}$ HEPES, 1 mM EDTA, 1 mM DTT, 2 mM ATP pH 7.4 (Panel A). Units for the integrated area under the curves (AUC) are photons. If the two conjugates were reduced with 1mM DTT for 20 minutes prior to exposure to firefly luciferase a profile of luminescence similar to that seen for luciferin was observed. Importantly, equivalent amount of light was produced for both conjugates.

\section{Cellular Assays for luciferin release from conjugates $5 b$ and $5 c$}

A prostate tumor cell line, stably transfected with luciferase, PC3M-luc, was plated at 60,000 cells per well in 96 well, flat bottomed plates twelve hours prior to the assay. The cells were incubated with varying concentrations of either the potassium salt of luciferin (Xenogen Corp., Alameda, CA) or carbonates $\mathbf{5 b}$ or $\mathbf{5 c}$, in triplicate, for 1 minute, in either Hepes buffered saline (HBS) pH 7.4 or K+HBS The cells were washed, resuspended with the appropriate buffer, and the resultant luminescence was measured using a charged coupled device camera and Living Image software ((IVIS200, Xenogen, Corp., Alameda, CA).

\section{Assays measuring the release of luciferin from and decomposition of conjugates 5 a-c}

Each of the conjugates $(0.2 \mathrm{mg})$ were dissolved in $250 \mu \mathrm{L}$ HBS pH 7.4 in $1.5 \mathrm{~mL}$ microfuge tubes and incubated at $37{ }^{\circ} \mathrm{C}$ containing $10 \mu \mathrm{L}$ of a solution of $10 \mathrm{mg}$ of 1-naphthalenemethanol in $24 \mathrm{~mL}$ of methanol, which served as an internal standard. At appropriate time points $20 \mu \mathrm{L}$ of the solutions were removed and analyzed by reverse phase HPLC. The percent decomposition was calculated from the 
integrated peak areas of the conjugate, the internal standard, and the various decomposition products. 